\title{
Recent Approaches on the Renin-Angiotensin System in Male Reproduction
}

\author{
W.B. Schill, F.M. Köhn, W.Miska
}

\begin{abstract}
Abtrak
Sistem renin-angiotensin yang sangat dikenal dalam pengaturan tekanan darah, sebenarnya merupakan sistem yang sangat kompleks dan menunjukkan interaksi dengan berbagai sistem lainnya. Baru-baru ini, beberapa penemuan menunjukkan kemungkinan keterlibatan sistem ini dalam fungsi reproduksi pria. Sejumlah besar angiotensin converting enzyme (ACE), yang merupakan enzim utama dalam sistem ini, tidak hanya ditemukan dalam paru-paru dan ginjal, tapi juga dalam organ reproduksi pria. Pada manusia, ACE terdapat dalam dua isoenzim yang berbeda, isoenzim testis dan serum. ACE dalam testis merupakan bagian C-terminal dari enzim yang terdapat di paru-paru dengan berat molekul $80 \mathrm{kDa}$ dan terdiri dari 701 residu asam amino. ACE testis merupakan produk mRNA spesifik dari testis dan pengaturannya tergantung pada androgen. Walaupun secara biokimiawi ACE sudah dikenal secara lengkap, namun fungsi biologisnya belum diketahui. Pada tikus, kadar ACE yang tertinggi ditemukan pada testis dan epididimis. Kadarnya semakin meningkat dari kaput sampai ke kauda epididimis. Namun terdapat perbedaan antar berbagai spesies. Kadar tertinggi ditemukan pada testis dan epididimis mencit, dan kadar terendah pada kerbau dan kelinci. Adanya gradien kadar ACE dalam epididimiss menunjukkan bahwa ACE sangat mungkin berperan pada proses pematangan sperma. ACE testis nampaknya ada hubungannya dengan membran spermatosit. Penelitian pada semen ternak menunjukkan bahwa selama inkubasi, ACE dilepaskan dari sperma ke dalam medium kapasitasi.
\end{abstract}

\begin{abstract}
The renin-angiotensin system, a complex biological system which is well known in the regulation of blood pressure has indeed multiple interaction with other regulatory system. Recently, several findings have also pointed to a possible involvement of this system in male reproductive function. High amounts of angiotensin converting enzyme (ACE), the main regulatory enzyme of this system, do not only occure within the human lung and kidney, but also in the male genital tract. In man, ACE occurs in two structurally dissimilar isoenzymes, a testicular and a serum form. Testicular ACE represents the C-terminal half of the lung enzyme with a molecular mass of $80 \mathrm{kDa}$ and 701 amino acid residues. Testicular ACE is the product of a testis specific $m R N A$ and is hormonally regulated depending on androgen. While ACE has been completely characterized biochemically, its biological role is still unknown. In the rat, the highest ACE activities are found in the testis and epididymis. Increasing concentrations are observed from the caput to the cauda epididymis. However, differences seem to exist among various species, with highest ACE level in the mous testis and epididymis, lowest level in bufallo and rabbit. The observed gradient of ACE concentrations within the epididymis indicates that ACE may play a certain role in sperm maturation. Testicular ACE seems to be associated with membranes of spermatocytes. Studies of cattle semen demonstrated that $A C E$ is released from spermatozoa during incubation in capacitation medium.
\end{abstract}

Keywords : Renin-angiotensin system, male reproduction

The renin-angiotensin system is a complex biological system and has multiple interactions with other regulatory systems, particularly the kallikrein-kinin system. ${ }^{1,2}$ The renin-angiotensin system is wellknown in the regulation of blood pressure. ${ }^{3}$ However,

Department of Dermatology and Andrology, Justus Liebig University, Giessen, Germany

Author's address :

Prof. Dr. W.-B. Schill, Universitāts-Hautklinik,

Gaffkystr. 14, D-35385 Giessen, Germany. several findings have also pointed to a possible involvement of this system in male reproductive functions. ${ }^{4}$

The main regulatory enzyme of the renin-angiotensin system is the angiotensin converting enzyme (ACE), a membrane-bound glycoprotein which is detectable in all tissues and body fluids of mammals. ${ }^{5,6}$ ACE plays a significant role in the regulation of blood pressure. Complete inhibitions of ACE by Captopril has been used with great success in hypertensive patients. The primary cellular location of ACE was found in vascular endothelial cells near the luminal surface, juxtaposed to the blood circulation. ${ }^{5,7}$ High amounts of ACE do not only occur within the human lung and kidneys, but 
also in the male genital tract, indicating that it is most probably involved in reproductive functions. ${ }^{6}$

Angiotensin converting enzyme catalyzes the conversion of the decapeptide angiotensin I to the vasoconstrictor angiotensin II. At the same time, it is a potent kinin-inactivating enzyme identical with kinanse II. Angiotensin converting enzyme inactivates bradykinin by releasing the C-terminal dipeptidyl residue Phe-Arg. In seminal plasma, two major kininases are present : ACE and neutral metallo-endopeptidase. ${ }^{8}$ Neutral endopeptidase (NEP or enkephalinase) cleaves bradykinin at the same peptide bond as kininase II. NEP, a $\mathrm{Zn}^{++}$containing endopeptidase, was first detected by Kerr and Kenny in 1974 in kidney brush border. ${ }^{9}$ Although NEP and ACE release the same dipeptide from bradykinin, most of their other properties, including substrate specificities, differ greatly. NEP activity is high in human seminal fluid and particular fractions of epididymis and prostate, but low in testicular homogenate. Prostatic NEP has a higher carbohydrate content than the renal enzyme. Malfroy et al. cloned NEP from human placental cDNA library in 1988. It contains 742 amino acids in a well-conserved sequence : the rat and rabbit enzymes are highly homologous with the human enzyme. ${ }^{10}$

In man, $\mathrm{ACE}$ occurs in two structurally dissimilar isoenzymes: ${ }^{11}$ one isoenzyme $(140 \mathrm{KDa})$ is produced by somatic tissues such as lung, kidney and vascular endothelium; the other isoenzyme is unique to the testis. Both isoenzymes are produced by transcription of the same gene. As in other mammals, the human testis expresses both isoenzymes. Apart from the germinal epithelium, $\mathrm{ACE}$ is also found in Leyding cells. The ratio between somatic and testicular ACE is $1: 4$ in human testis.

Since human testicular ACE was cloned, ${ }^{12}$ its amino acid sequence is known. It represents the C-terminal half of the lung enzyme with a molecular mass of 80 $\mathrm{kDa}$ and 701 amino acid residues. Testicular ACE is the product of a testis-specific mRNA, which is hormonally regulated by androgens. It has been confirmed by various animal studies that ACE production in the testis of rats, rabbits and mice is dependent on sexual maturation and seems to be controlled by the pituitary system and androgens. ${ }^{13}$

$\mathrm{ACE}$ was also found in other regions of the human genital tract, as in the prostate gland, epididymis, vas deferens and seminal vesicles. ${ }^{6}$ High concentrations are present in the seminal plasma. Kininase II of seminal plasma corresponds to the somatic isoenzyme and is mainly produced by the prostate and seminal vesicles. While $\mathrm{ACE}$ has been completely characterized biochemically, its biological role within the male reproductive tract is still unknown. Sibony et al. ${ }^{14}$ found it to be exclusively produced in haploid germ cells in murine testis and belongs to proteins that are expressed during definite maturation steps of spermiogenesis; this process appears to be correlated with germ cell differentiation. ${ }^{14}$ This strongly supports the hypothesis of a local renin-angiotensin system within the seminiferous tubules.

In the rat, highest $\mathrm{ACE}$ activities are found in the testis and epididymis. Its activity is androgen-dependent. From the caput to the cauda epididymidis, increasing concentrations are observed. ${ }^{13}$

However, differences seem to exist among various species, with highest ACE levels in the mouse testis and epididymis, lowest levels in buffalo and rabbit. ${ }^{13}$ The observed gradient of ACE concentrations within the epididymis indicates that ACE might play a role in sperm maturation. This has been supported by the group of Hilse ${ }^{15}$ who fed $\mathrm{ACE}$ inhibitors to rats during puberty. Another study demonstrated an effect of ACE on the anion secretion of the rat epididymis ${ }^{16}$, suggesting that spermatozoa control epididymal functions by release of $\mathrm{ACE} .^{17}$

ACE was found in the acrosomes and cytoplasmic droplets of epididymal boar spermatozoa ${ }^{18}$ and in the cytoplasmic droplets of testicular, epididymal and ejaculated spermatozoa of rabbits. ${ }^{19}$ However, the exact location of ACE in ejaculated human spermatozoa is still unknown. It was shown to be present in the acrosomal cap of human ${ }^{5}$ and rat spermatids. ${ }^{20}$ A possible correlation between ACE release and capacitation was first described by Singh and coworkers $^{21}$ and Foresta and coworkers ${ }^{22}$ using cattle and human semen, respectively.

Foresta and coworkers ${ }^{22}$ demonstrated considerable release of ACE during incubation of spermatozoa in capacitation medium (BWW containing 3.5\% HSA), whereas incubation in Krebs-Ringer solution (KRS) showed only small amounts of ACE release. It was possible to reduce $\mathrm{ACE}$ release in a dose-dependent manner by addition of different concentrations of the ACE inhibitor captopril. High concentrations of captopril $(100 \mathrm{nmol} / \mathrm{l})$ reduced ACE activity to the level observed in KRS-incubated spermatozoa.

Our own studies confirmed these observations. ${ }^{23}$ High amouts of ACE were released from spermatozoa after 
detergent treatment, e.g. with Triton X, NP-40, Thesit and CHAPS. In other experiments, glass wool-filtered and washed human spermatozoa were capacitated for 3 hours at $37^{\circ} \mathrm{C}$. The percentages of acrosome-reacted and dead spermatozoa did not change significantly, but the release of $\mathrm{ACE}$ increased from 0 to 2.93 $\mathrm{mU} / 100 \times 10^{6}$ spermatozoa. The data suggest that ACE is present in ejaculated human spermatozoa and can be released during capacitation in vitro.

Since ACE is known to be a membrane-bound enzyme, membrane changes during capacitation could explain the release of this *enzyme. Studies by Broadleyet al. ${ }^{24}$ demonstrated increased ACE activity after removal of cholesterol from endothelial cell membranes. During capacitation, the cholesterol content of the human sperm plasma membrane is also reduced. In conclusion, measurement of $\mathrm{ACE}$ release may be a clinically useful assay for human sperm capacitation. This topic is presently under investigation in our laboratories.

Considering the acrosome reaction, ${ }^{22}$ demonstrated that captopril reduced the percentage of acrosomereacted spermatozoa after incubation in a capacitation medium. Thus, captopril is able to inhibit the acrosome reaction in vitro. Based on the close correlation between the acrosome reaction and the HOP test, ${ }^{22}$ also found impaired sperm penetration rates in the hamster egg test using the ACE inhibitor captopril.

This supports the hypothesis that ACE of human spermatozoa may be involved in the induction of the acrosome reaction which is essential for ovum fertilization.

We will now consider another aspect of ACE : its possible role in the regulation of sperm motility.

In man, about $40 \%$ of $\mathrm{ACE}$ in the seminal plasma originate from the testis and epididymis, whereas $60 \%$ come from the prostate. ${ }^{6}$ In the prostate, ACE is mainly associated with macromolecular structures that have been identified as membrane vesicles in the seminal plasma, with a diameter of $100 \mathrm{~nm}$ or less. ${ }^{26}$ These membrane vesicles are identical with the so-called "prostasomes" described by Ronquist at al. ${ }^{25}$ who found stimulating effects of prostasomes on sperm motility in vitro. ${ }^{27} \mathrm{~A}$ possible role of ACE from the prostasomes in the regulation of sperm motility was suggested, but has not yet been confirmed by other authors.
Kaneko and Moriwaki ${ }^{28,29}$ abserved a good correlation between seminal plasma ACE activity, sperm motility, and sperm count. Investigations by Helbrugger et $\mathrm{al}^{30}$ did not confirm these results. Our own studies with determination of ACE activities in human semen samples failed to give evidence of a correlation between ACE activity and sperm motility. However, a significant correlation to sperm count was demonstrated, which confirms Kaneko's work (Schill and Miska, unpublished).

A comparison of normozoospermic and oligozoospermic ejaculates showed a significant decrease of $\mathrm{ACE}$ in the latter group. Further reduction in ACE activity, due to spermatogenic arrest, was found in azoospermia (Schill and Miska, unpublished).

Recent observations demonstrated stimulation of sperm motility in the presence of millimolar concentrations of captopril, suggesting that a direct effect of $\mathrm{ACE}$ on sperm motility is not very probable. ${ }^{31}$ Motility stimulation by high concentrations of captopril may result from an alphamimetic side-effect of this ACE inhibitor. High concentrations of captopril may, however, also lead to complete inhibition of $N E P$, which could result in increased bradykinin concentrations that stimulate sperm motility.

On the other hand, a stimulating effect of angiotensin I and II on the velocity of washed human spermatozoa was observed ${ }^{29,32}$, which is comparable to that of bradykinin, whereas angiotensin III was ineffective. Suppression of the stimulating effect of angiotensin II on sperm motility by saralasine ([Sar ${ }^{1}, \mathrm{Val}^{5}, \mathrm{Ala}^{8}$ ] ATII), a specific antagonist of angiotensin II, indicated that this action on spermatozoa appeared to be mediated via a specific angiotensin II receptor on the plasma membrane. ${ }^{29}$

A possible significance of the renin-angiotensin system in reproductive functions is further supported by the identification of renin and low amounts of angiotensinogens in the seminal plasma. ${ }^{32}$

In addition, the renin-angiotensin system has been suggested to be involved in the paracrine regulation of testicular functions because of intracellular formation of angiotensin I and angiotensin II in rat Leyding cells and the occurrence of angiotensin II receptors in rat, rhesus monkey, and human Leydig cells. ${ }^{33}$ Thus, angiotensins may have a regulatory role in modulating paracrine Leydig cell function. 
A close connection between the renin and the kinin system has been demostrated. Experimental and clinical studies have shown a possible role of the kallikreinkinin system in sperm motility. ${ }^{2}$ Furthermore, kinins may possibly be involved in the modulation of spermatogenesis. This seems to be remarkable since ACE is the key regulatory enzyme between the kallikreinkinin system and the renin-angiotensin system. Kinins have been shown to be the terminal effectors of the kallikrein-kinin system in that they increase sperm motility and sperm velocity at nanomolar concentrations. $^{34}$

As we demonstrated, kinins are continously liberated through limited proteolysis from kininogens in the seminal plasma. ${ }^{35}$ On the orther hand, the level of free kinins in the seminal plasma is regulated by the kinindegrading peptidase ACE. Inhibition of ACE should increase kinin levels and, consequently, sperm motility. This hypothesis is in part supported by a controlled, double-blind randomized study using the ACE inhibitor captoril in 58 patients with idiopathic oligozoospermia and asthenozoospermia. ${ }^{36}$ Semen analyses were performed under standarlized conditions 4 weeks before and at the start of treatment as well as 4 and 12 weeks after initiation of therapy.

Apart from the evaluation of semen parameters according to WHO recommendations, differential blood count, renal profile, gonadotropins and testosterone were determined at the initial pretreatment visit and after 4 and 12 weeks of therapy. Furthermore, blood pressure was controlled at each visit. Captopril was administered orally at a dosage of $25 \mathrm{mg}$ twice daily. No severe side-effects were noted during the clinical trial. After 12 weeks of therapy, sperm counts were found to be significantly improved in the captopril group compared to the placebo controls.

In addition, level differences (mean of two semen analyses) before and during treatment showed a significant increase of sperm count during captopril therapy compared to the placebo group. All other semen parameters, in particular sperm motility, hormonal and blood values and blood pressure, remained unchanged. The conception rate, defined as number of pregnancies within one year after initiation of therapy, was $19 \%$ in the captopril group compared to $28 \%$ in the placebo group. The difference was statistically not significant.

Improvement of sperm count during captopril treatment indicates a moderate stimulation of spermatogenesis, which may be related to an inhibition of
ACE. This may lead to increased kinin levels within the male genital tract and could directly stimulate tubular functions. However, it is not yet known whether captopril is able to penetrate the blood-testis and the blood-seminal plasma barrier. Therefore, ACE activity and kinin levels in the seminal plasma were investigated during the placebo-controlled study. ${ }^{36}$

During oral captopril therapy, ACE activity in the seminal plasma was significantly decreased compared to the placebo group. This might indicate that captopril is transudated through the blood- testis or the bloodseminal plasma barrier and leads to an inhibition of ACE activity. Determination of kinin levels in seminal plasma by a radioimmunoassay revealed significantly higher kinin levels during captopril treatment, which supports our concept of improved sperm function due to increased kinin levels.

However, Hilse and coworkers ${ }^{15}$ showed that ramipril, a low molecular weight inhibitor of ACE comparable to captopril, is unable to pass the blood testis barrier in rats. This indicates that captopril is probably transudated into seminal plasma by exclusively passing the blood-seminal plasma barrier. Hence, an indirect effect on the cells of spermatogenesis via enhanced bradykinin levels in the blood plasma should be discussed, which could interact with Leyding or Sertoli cell function.

The presumed indirect action on spermatogenesis is perhaps also responsible for the kallikrein-mediated improvement of spermatogenesis. Surprisingly, captopril had no influence on sperm motility, as had been expected because of increased kinin levels.

Improved sperm count during captopril treatment may suggest that the renin-angiotensin system is involved in the paracrine regulation within the mammalian testis. Captopril may change Leydig cell function by a alteration in the production of angiotensin II which is produced by these cells.

A possible effect of the renin-angiotensin on male fertility has also been discussed by Habenicht and coworkers $^{37}$ who investigated transgenic rats bearing the renin gene. Introduction of the mouse Ren- 2 gene into the genome of rats did not only cause severely high blood pressure but also gave rise to lines associated with male infertility. A remarkable thickening of the wall of the arterioles was evident, which was caused by hypertrophy of the media. Neither in normotensive nor in spontaneously hypertensive rats were these al- 
A close connection between the renin and the kinin system has been demostrated. Experimental and clinical studies have shown a possible role of the kallikreinkinin system in sperm motility. ${ }^{2}$ Furthermore, kinins may possibly be involved in the modulation of spermatogenesis. This seems to be remarkable since ACE is the key regulatory enzyme between the kallikreinkinin system and the renin-angiotensin system. Kinins have been shown to be the terminal effectors of the kallikrein-kinin system in that they increase sperm motility and sperm velocity at nanomolar concentrations. ${ }^{34}$

As we demonstrated, kinins are continously liberated through limited proteolysis from kininogens in the seminal plasma. ${ }^{35}$ On the orther hand, the level of free kinins in the seminal plasma is regulated by the kinindegrading peptidase ACE. Inhibition of ACE should increase kinin levels and, consequently, sperm motility. This hypothesis is in part supported by a controlled, double-blind randomized study using the ACE inhibitor captoril in 58 patients with idiopathic oligozoospermia and asthenozoospermia. ${ }^{36}$ Semen analyses were performed under standarlized conditions 4 weeks before and at the start of treatment as well as 4 and 12 weeks after initiation of therapy.

Apart from the evaluation of semen parameters according to WHO recommendations, differential blood count, renal profile, gonadotropins and testosterone were determined at the initial pretreatment visit and after 4 and 12 weeks of therapy. Furthermore, blood pressure was controlled at each visit. Captopril was administered orally at a dosage of $25 \mathrm{mg}$ twice daily. No severe side-effects were noted during the clinical trial. After 12 weeks of therapy, sperm counts were found to be significantly improved in the captopril group compared to the placebo controls.

In addition, level differences (mean of two semen analyses) before and during treatment showed a significant increase of sperm count during captopril therapy compared to the placebo group. All other semen parameters, in particular sperm motility, hormonal and blood values and blood pressure, remained unchanged. The conception rate, defined as number of pregnancies within one year after initiation of therapy, was $19 \%$ in the captopril group compared to $28 \%$ in the placebo group. The difference was statistically not significant.

Improvement of sperm count during captopril treatment indicates a moderate stimulation of spermatogenesis, which may be related to an inhibition of
ACE. This may lead to increased kinin levels within the male genital tract and could directly stimulate tubular functions. However, it is not yet known whether captopril is able to penetrate the blood-testis and the blood-seminal plasma barrier. Therefore, ACE activity and kinin levels in the seminal plasma were investigated during the placebo-controlled study. ${ }^{36}$

During oral captopril therapy, ACE activity in the seminal plasma was significantly decreased compared to the placebo group. This might indicate that captopril is transudated through the blood- testis or the bloodseminal plasma barrier and leads to an inhibition of ACE activity. Determination of kinin levels in seminal plasma by a radioimmunoassay revealed significantly higher kinin levels during captopril treatment, which supports our concept of improved sperm function due to increased kinin levels.

However, Hilse and coworkers ${ }^{15}$ showed that ramipril, a low molecular weight inhibitor of ACE comparable to captopril, is unable to pass the blood testis barrier in rats. This indicates that captopril is probably transudated into seminal plasma by exclusively passing the blood-seminal plasma barrier. Hence, an indirect effect on the cells of spermatogenesis via enhanced bradykinin levels in the blood plasma should be discussed, which could interact with Leyding or Sertoli cell function.

The presumed indirect action on spermatogenesis is perhaps also responsible for the kallikrein-mediated improvement of spermatogenesis. Surprisingly, captopril had no influence on sperm motility, as had been expected because of increased kinin levels.

Improved sperm count during captopril treatment may suggest that the renin-angiotensin system is involved in the paracrine regulation within the mammalian testis. Captopril may change Leydig cell function by a alteration in the production of angiotensin II which is produced by these cells.

A possible effect of the renin-angiotensin on male fertility has also been discussed by Habenicht and coworkers $^{37}$ who investigated transgenic rats bearing the renin gene. Introduction of the mouse Ren-2 gene into the genome of rats did not only cause severely high blood pressure but also gave rise to lines associated with male infertility. A remarkable thickening of the wall of the arterioles was evident, which was caused by hypertrophy of the media. Neither in normotensive nor in spontaneously hypertensive rats were these al- 
terations observed in comparative studies. Cauda epididymal spermatozoa were completely immotile. These preliminary data give some hints of an association between the renin-angiotensin system and impairment of spermatogenesis based on disturbed testicular blood flow.

In addition, the results of the clinical trial with captoril reported here support a possible involvement of the renin- angiotensin system in both the paracrine regulation of testicular function and sperm motility.

In summary, the following conclusions can be drawn :

According to various biochemical and clinical findings, the renin-angiotensin system, in particular ACE, seems to play a significant role within the male reproductive tract. It is probably involved in the following functions :

1. Spermatogenesis (paracrine regulatory function at the testicular level, supported by demonstration of angiotensin II receptors at the Leydig cell and on spermatozoa, and by correlation of seminal plasma ACE with sperm count and therapeutic effect of captopril).

2. Involvement in sperm maturation due to an $\mathrm{ACE}$ gradient at the epididymal level.

3. Involvement during capacitation and the acrosome reaction, since ACE of spermatozoa will be activated in cytoplasmic residues of sperm under capacitation conditions.

4. There is still controversy about whether the angiotensin system is involved in the regulation and maintenance of sperm motility. However, indirect effects may be possible, which remain to be elucidated.

\section{REFERENCES}

1. Peach M. Renin-angiotensin system : Biochemistry and mechanism of action. Physiol. Rev. 1977; 57:313-55.

2. Schill W-B, Miska W. Possible effects of the kallikrein-kinin system on male reproductive functions. Andrologia 1992; 24:69-75

3. Ondetti M, Cushman D. Enzymes of the renin angiotensin system and their inhibitors. Ann Rev Biochem. 1982; 51:283-308

4. Cushman DW, Cheung HS, Concentrations of angiotensinconverting enzyme in tissues of the rat. Biochim Biophys Acta $1971 ; 250: 261-5$

5. Vivet F, Callard P, Gamoudi A. Immunolocalization of angiotensin I converting enzyme in the human male genital tract by the avidin-biotin-complex method. Histochemistry 1987; 86:499-502
6. Krassnigg F, Niederhauser H, Fink E, Frick J, Schill W-B. Angiotensin converting enzyme in human seminal plasma is synthesized by the testis, epididymis and prostate. Int $\mathrm{J}$ Androl 1989; 12:22-8

7. Caldwell P, Seegal P, Hsu K, Das M, Soffer R. Angiotensin converting enzyme : Vascular endothelial localization. Science 1976; 191:1050

8. Erdös E, Schulz W, Gafford J, Defendini R. Neutral metalloendopeptidase in human male genital tract. Lab Invest $1985 ; 52: 437-77$

9. Kerr MA, Kenny AJ. The purification and specificity of a neutral endopeptidase from rabbit kidney brush border. Biochem J 1974; 137:477-88

10. Malfroy B, Kuang WJ, Seebarg PH, Mason AJ, Schofield PR. Molecular cloning and amino acid sequence of human enkephalinase (neutral endopeptidase). FEBS Lett. 1988; 229:206-10.

11. Singh US, Srivastava AK. Angiotensin converting enzyme from capacitated rabbit spermatozoa : Two distinct forms. Andrologia 1988; 20:322-5

12. Ehlers MRW, Fox EA, Strydom J, Riordan JF. Molecular cloning of human testicular angiotensin-converting enzyme : The testis isozyme is identical to the C-terminal half of endothelial angiotensin-converting enzyme. Proc Natl Acad Sci USA 1989; 86:7741-45

13. Jaiswal A, Joship, Kumar MV, Panda JN, Singh LN. Angiotensin converting enzyme in the testis and epididymis of mammals. Andrologia 1984; 16:410-6

14. Sibony M, Segretain D, Gasc JM. Angiotensin-converting enzyme in murine testis : Step-specific expression of the germinal isoform during spermiogenesis. Biol Reprod 1994; 50:1015-26

15. Hilse H, Siems WE, Heder G, Stahl F, Jentzsch KD. The influence of ramipril on blood pressure, ACE activity, sperm density and motility of spontaneously hypertensive rats during puberty. Pharmazie 1991; 46:360-1

16. Wong PYD, Fu WO, Huang SJ, Law WK. Effect of angiotensins on electrogenic anion transport in monolayer cultures of rat epididymis. J Endocrinol 1990; 125:449-56

17. Wong PYD, Uchendu CN. The role of angiotensin-converting enzyme in the rat epididymis. J Endocrinol 1990 125:457-65

18. Yotsumoto H, Sato S, Shibuya M. Localization of Angiotensin converting enzyme (dipeptidyl carboxypeptidase) in swine sperm by immunofluorescence. Life Sciences 1984 35:1257-61

19. Brentjens JR, Matsuo S, Andres GA, Caldwell PRB, Zamboni L. Gametes contain angiotensin converting enzyme (kininase II). Experientia 1986; 42:399-402

20. Strittmatter SM, Snyder SH. Angiotensin-converting enzyme in the male rat reproductive system : autoradiographic visualization with [3H] captopril. Endocrinology 1984; 115:2332-41

21. Singh US, Kumar MV, Panda JN. Angiotensin converting enzyme in semen and its possible role in capacitation. Andrologia $1985 ; 17: 472-5$

22. Foresta C, Indino M, Manoni F, Scandellari C, Angiotensin converting enzyme content of human spermatozoa and its release during capacitation. Fertil Steril 1987; 47:1000-3. 
23. Köhn FM, Miska W, Schill W-B. Release of angiotensinconverting enzyme (ACE) from human spermatozoa during capacitation and acrosome reaction. J Androl (submitted) 1994

24. Broadley C, Dawidowicz E, Chong PLG, Hoover R. Modulation of membrane cholesterol levels : effects on endothelial cell function. Exp Cell Res 1991; 193:144-50

25. Ronquist G, Nilsson O, Hjerten S. Interaction between prostasomes and spermatozoa from human semen. Arch Androl $1990 ; 24: 147-57$

26. Krassnigg F, Niederhauser H, Fink E, Frick J, Schill WB. Angiotensin converting enzyme (ACE) of human seminal plasma is synthesized by the testis, epididymis and prostate. Int J Androl 1989; 12:22-8.

27. Stegmayr B, Ronquist G. Promotive effect of human sperm progressive motility by prostasomes. Urol Res 1982; 10:253-7

28. Kaneko S, Moriwaki C. Studies on dipeptidyl carboxypeptidase in the male reproductive organs; its biological and pathological status. J Pharm Dyn 1981; 4:175-83

29. Kaneko S, Oshio S, Kobayashi T, Iizuka R. Effects of angiotensins on the motility of human sperm. J Pharm Dyn $1984 ; 7: 87-93$

30. Hohlbrugger G, Pschorr J, Dahlheim H, Angiotensin I converting enzyme in the ejaculate of fertile and infertile men. Fertil Steril 1984; 41:324-61
31. Placzek R, Krassnigg F, Schill W-B. Effect of ACE-inhibitors, calmodulin antogenists, acetylcholine receptor blocking. and alpha receptor blocking agents on motility of human sperm. Arch Androl 1988; 21:1-10

32. Mizutani T, Schill W-B. Motility of seminal plasma-free spermatozoa in the presence of several physiological compounds. Andrologia 1985; 75:150-6

33. Khanum A, Dufau ML. Angiotensin II receptors and inhibitory actions in Leydig cells. J Biol Chem 1988; 263:5070-4

34. Miska W, Schill W-B. Enhancement of sperm motility by bradykinin and kinin analogs. Arch Androl 1990; 25:63-7

35. Fink E, Schill W-B, Miska W, Kinin-containing kininogen is present in human seminal plasma. In : Abe $\mathrm{K}$, Moriya $\mathrm{H}$, Fuji S (eds) Kinins V, Part B. Plenum Press, New York, London $1989 \mathrm{pp}$ 311-5

36. Schill W-B, Parsch EM, Miska W. Inhibition of angiotensinconverting enzyme - a new concept of medical treatment of male infertility? Fertill Sterill 1994; 61:1123-8

37. Habenicht UF, Ganten U, Mullins JJ, Ganten D. Does the renin-angiotensin system affect male fertility in rats? Exp Clin Endocrinol 1993; 101 (Suppl 1):134. 